\title{
The sea-defence function of micro-tidal temperate coastal wetlands
}

\author{
I. Möller ${ }^{1}$, J. Lendzion ${ }^{2}$, T. Spencer ${ }^{1}$, A. Hayes ${ }^{1} \&$ S. Zerbe ${ }^{3}$ \\ ${ }^{I}$ Cambridge Coastal Research Unit, Department of Geography, \\ University of Cambridge, UK \\ ${ }^{2}$ Institute of Botany and Landscape Ecology, \\ University of Greifswald, Germany \\ ${ }^{3}$ Faculty of Science and Technology, \\ Free University of Bozen, Italy
}

\begin{abstract}
Global environmental change poses a growing challenge for the management of low-lying coastal environments. The challenge is to (a) recognise and quantify the ecological functions of such environments, and (b) develop management approaches that allow those functions to be maintained in the context of global change. Meeting this challenge is particularly important on micro-tidal shorelines, where the ecological sensitivity to sea level rise and changing climatic conditions (e.g. storm frequency and intensity) is likely to be high.

This study addresses the need to quantify the wave-dissipating function of these types of coastal wetland. Previous studies have focused on tidal coasts and salt marsh or mangrove vegetation and have highlighted relationships between coastal wetland vegetation type, water depths, and observed wave energy reduction. Prior to this study, however, no data was available on the sea-defence function of coastal grasslands and reed beds, where irregular inundation by meteorologically driven storm surges dominates over tidal inundation.

Results are presented of wave and vegetation monitoring along three crossshore transects at the fringes of reed beds and coastal brackish grasslands on the German Baltic shoreline. The data highlight significant differences in the seadefence function of these two types of micro-tidal coastal habitat, highlighting important differences in the likely response to future climatic (and sea level) changes and raising questions around how these functions might be maintained, enhanced, or restored in the context of environmental change.
\end{abstract}

Keywords: sea level rise, wave dissipation, baltic coastal wetlands, coastal management. 


\section{Introduction}

Coastal wetlands have been identified as fulfilling a range of key ecological, morphological, and sea-defence functions within the coastal zone (Allen and Pye [1]). The importance of understanding these functions is likely to increase in the context of global environmental change, in particular relative sea-level rise, wave climate change, and the need for new coastal management approaches to accommodate these environmental shifts.

Particular concern has been raised about the future functioning of intertidal coastal habitats under an acceleration in sea level, as recorded in the last decade and the expected acceleration over the remainder of the twenty first century. A proper assessment of the vulnerability and sustainability of these systems needs to establish the range of both coastal marsh types present and the process environments within which they are found. Thus, for example, there is a need for the more systematic investigation of the notion that wetlands maintaining equilibrium under a macro-tidal range may have greater resilience towards the impacts of sea-level rise than a system operating under a narrow range of tidal fluctuations (e.g. French [2]). Such micro-tidal systems depend to a greater degree on storm-driven sedimentation, raising issues about the interactions between storminess, wave action, sediment supply and system maintenance (e.g. Bartholdy et al. [3]). Ultimately, therefore, the existence of coastal wetlands, and the provision of their valuable ecological functions, are crucially dependent upon shallow water hydrodynamics.

One important component in this regard is the wave dissipating function of vegetation present at the coastal fringe. Previous studies of wave attenuation have shown that both micro- and macro-tidal coastal saltmarshes significantly attenuate incident wave energy (e.g. Knutson et al. [4] and Möller et al. [5]), thus protecting landward habitats from wave impact. Cliffed marsh to mudflat transitions, often the result of differential erosion at the fringes of the vegetated upper intertidal profile, may themselves significantly alter cross-shore wave energy distribution (Möller and Spencer [6]). As well as influencing coastal marsh ecology, any alteration in wave energy levels due to the presence of vegetation, or cliffed marsh edges, has implications for sediment erosion, transport, and deposition and thus for the future functioning of the coastal wetland.

\section{Field site}

Although most Baltic salt grasslands are small, associated with emergent rocky shores and waters of low salinity, they do occur on sedimentary shorelines outside the influence of glacial rebound. Tidal variations in the Baltic Sea are insignificant and water-level fluctuations are determined by atmospheric forcing and, in some areas, by river discharge. Average water level variations between spring and summer in the central Baltic Sea are $23 \mathrm{~cm}$ (Tyler [7]) and average winter sea surface heights (December to February) have been modelled to be up to $90 \mathrm{~cm}$ higher than average annual sea surface heights for the period 1961 to 
1991 (Meier et al. [8]). Gillner [9] records an extreme annual variation in water level of $370 \mathrm{~cm}$ at the Polish-German border.

The two locations at which field measurements were made are situated on the southwestern fringes of the Greifswalder Bodden, eastern Germany, to the south of the Island of Rügen, southern shore of the Baltic Sea (Figure 1). The area lies in the region of salinities of 10-5 parts per thousand (Jeschke [10]), considerably less than the transition area from fully marine conditions between Denmark and south-west Sweden but greater than the salinities recorded in the Gulf of Finland and Gulf of Bothnia (Tyler [7]). Along these shores, brackish water reeds (Phragmites australis) are common. The salt grasslands not dominated by reeds are mostly of anthropo-zoogenic origin and have developed after semicontinuous grazing (Jeschke [10]). Restoration projects in the past decade have been focussed on the maintenance of specific habitats (Seiberling et al. [11]); here grazing is currently applied to maintain coastal biodiversity.

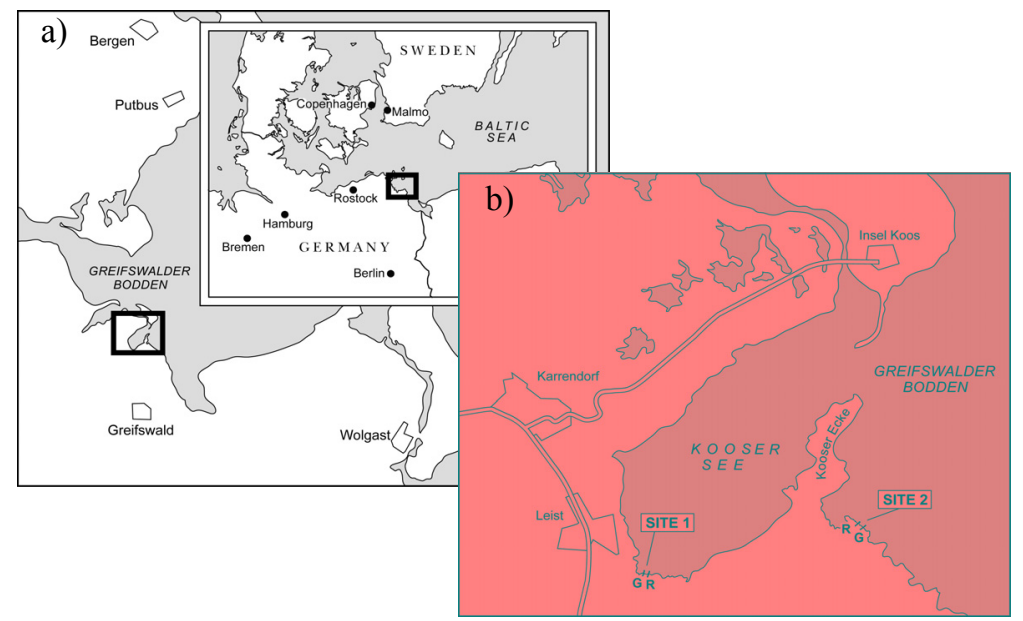

Figure 1: Location of (a) Greifswalder Bodden in the context of the Baltic Sea, and (b) wave monitoring Site 1 and Site 2, with reed (R) and grassland $(\mathrm{G})$ transects, at the southern margin of the Kooser See, Greifswalder Bodden

The two locations differ with respect to their degree of exposure and height of cliff at the transition from unvegetated mudflat to vegetated salt grassland surface. Site 1, located on the southern margin of the Kooser See, was relatively sheltered, with limited fetch (1-3 km from a $\mathrm{N}$ to NE direction) and shallow water depths throughout the Kooser See $(\leq 1 \mathrm{~m})$. Site 2, located on the western side of the 'Kooser Ecke' (see Figure 1), was much more exposed, with fetch distances of between $20 \mathrm{~km}$ (from a N direction) and $>400 \mathrm{~km}$ (from a NNE direction) and with the $2 \mathrm{~m}$ depth contour located within one kilometre of the shore. 


\section{Methodology}

Wave conditions and water levels were recorded using pressure sensor technology at five locations along a shore-normal transect within mudflat to i) reed bed and ii) salt grassland transitions at each of the two field monitoring sites (see Figure 1).

Vegetation characteristics recorded in $1620 \times 20$ m quadrats selected randomly along each transect are summarised in Table 1. This shows that the reed vegetation at both sites was more or less similar in terms of its height (210 to $320 \mathrm{~cm}$ ), density ( 8 to 28 numbers of stems per quadrat), and dry biomass (33 to $100 \mathrm{~g}$ per quadrat). Salt grassland vegetation differed somewhat between the two sites, with Site 2 showing a greater height $(11-38 \mathrm{~cm}$ compared to 2-27 cm), density (160-610 compared to 30-600 stems per quadrat), and biomass (17-39 compared to 7-32 g per quadrat).

Table 1: Averages (and range) of vegetation height, number of plant stems, and biomass (dry weight) recorded in $20 \times 20 \mathrm{~cm}$ quadrats at all four measurement transects $(\mathrm{N}=16$ at each site).

\begin{tabular}{|l|l|l|l|l|}
\hline & \multicolumn{2}{|l|}{ Reeds } & Meadow \\
\hline & Site 1 & Site 2 & Site 1 & Site 2 \\
\hline Height (cm) & 257 & 252 & 10 & 18 \\
& $(210-320)$ & $(215-310)$ & $(2-27)$ & $(11-38)$ \\
\hline Number of & 27 & 19 & 242 & 360 \\
stems & $(8-30)$ & $(11-28)$ & $(30-600)$ & $(160-610)$ \\
\hline Biomass (g) & 84.5 & 65.9 & 15.8 & 25.9 \\
& $(35.8-100.2)$ & $(32.5-78.0)$ & $(6.6-32.2)$ & $(16.5-39.1)$ \\
\hline
\end{tabular}

Wave recording followed a methodology similar to that described by Möller [12] and Möller and Spencer [6]. Pressure sensors (Druck Ltd 'PTX1830') were mounted and firmly secured horizontally ca 5-10 cm above the mud surface, with data acquisition controlled by Campbell Ltd 'CR10' data loggers.

Figure 2 shows the cross-shore morphology along the reed bed wave recording transects for each of the sites shown in Figure 1. Due to the narrower fringing reed belt at Site 1, transect distances between the individual wave sensors were shortened relative to the transect at Site 2, but both sites were characterised by locally reduced elevations in the central section of the reed fringe (the location of the fourth wave recording sensor).

Water level was measured at the fourth (from seaward) sensor every three hours. If the water level exceeded $5 \mathrm{~cm}$ above the sensor, then wave records were obtained at the four most seaward sensors on the transect. In addition, wave records were obtained at all five sensors on the transect at 11:30 each day, whenever the fourth sensor measured water depths of more than $5 \mathrm{~cm}$ above the sensor.

Sub-surface water pressure was recorded at a frequency of $4 \mathrm{~Hz}$ and, for accurate subsequent Fast Fourier Transform (FFT) analysis, a total of $2^{12}$ (4096) pressure readings were obtained as part of each wave 'burst' (each ' burst' thus 

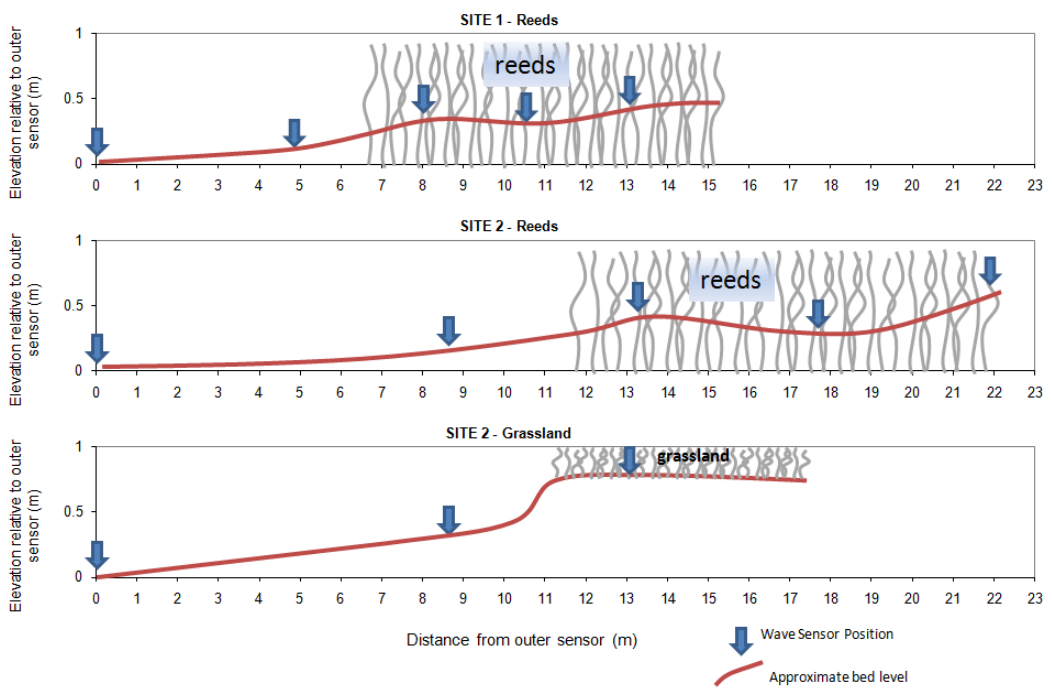

Figure 2: $\quad$ Surface elevation and horizontal distances between wave recording sensors along shore-normal transects at both sites (location of reed vegetation zone is indicated schematically) (for location of sites, see Figure 1).

lasting 17 minutes). A Matlab programme was used to post-process pressure records. The post-processing involved (i) de-trending of the pressure signal to eliminate any low frequency linear water level trend within the time series; (ii) determination of mean pressure / hydrostatic water depth; (iii) application of FFT algorithm for determination of wave frequency spectrum; (iv) frequency and depth dependent correction of the pressure signal to account for signal attenuation with depth; and (v) computation of accurate wave amplitude spectrum. The accuracy of this methodology has been proven by videocalibration in previously reported studies (see Möller et al [13]).

The final amplitude spectrum was used to derive the zero-upcrossing wave period $\left(\mathrm{T}_{\mathrm{z}}\right)$, significant wave height $\left(\mathrm{H}_{\mathrm{s}}\right)$, root-mean-square wave height $\left(\mathrm{H}_{\mathrm{rms}}\right)$, and total spectral energy $\left(\mathrm{E}_{\mathrm{tot}}\right)$.

\section{Results}

While the field wave recording equipment was deployed for the period October 2008 to February 2009, a series of factors affected data recovery. These included data logger malfunctioning, animal damage to the pressure sensor cables, and the freezing of the Baltic Sea along the coast from early January to late February 2009 , and meant that data recovery during the monitoring period was somewhat limited. Nevertheless, a total of 61 wave records were obtained for the wave recording transect through the reed vegetation at the sheltered Site 1 on the 'Kooser See', and a total of 39 records for the reed transect at the more exposed 
Site 2 (Figure 1). Three successful wave records were obtained for the salt grassland transects; these were all recovered from the more exposed Site 2. Meteorological data was obtained from the Deutscher Wetterdienst (DWD) to establish wind direction and speed at the time (to the nearest hour) each wave record was obtained. Table 2 provides a summary of those wave records that were included in further analysis, including the meteorological, water depth, and wave conditions. A total of 15 and 8 wave records at the reed transect of Site 1 and 2 respectively and all three records recovered from the salt grassland transect at Site 2 were obtained during northerly (i.e. onshore) winds (wind directions between 320 and 40 degrees from North).

Table 2: $\quad$ Summary wind, water depth, and wave conditions for all records obtained at Site 1 and 2 .

\begin{tabular}{|c|c|c|c|c|c|c|c|c|c|c|c|}
\hline & \multirow[t]{2}{*}{ Site } & \multirow[t]{2}{*}{$\mathrm{N}$} & \multicolumn{3}{|c|}{$\begin{array}{c}\text { Number of } \\
\text { observations during } \\
\text { wind direction }\end{array}$} & \multicolumn{2}{|c|}{$\begin{array}{c}\text { Water } \\
\text { depth } \\
\text { range }(\mathrm{m})\end{array}$} & \multicolumn{2}{|c|}{$\begin{array}{l}\text { Significant } \\
\text { wave } \\
\text { height }\left(H_{s}\right) \\
\text { range }(\mathrm{m})\end{array}$} & \multicolumn{2}{|c|}{$\begin{array}{l}\text { Zero- } \\
\text { upcrossing } \\
\text { Period }\left(T_{z}\right) \\
\text { range }(\mathrm{s})\end{array}$} \\
\hline & & & N'ly & $\begin{array}{l}\text { WNW/ } \\
\text { ENE }\end{array}$ & S'ly & Min & Max & Min & Max & Min & Max \\
\hline reed & 1 & 61 & 15 & 32 & 14 & 0.49 & 1.43 & 0.01 & 0.20 & 0.93 & 2.99 \\
\hline reed & 2 & 39 & 8 & 21 & 10 & 0.84 & 1.55 & 0.01 & 0.27 & 1.12 & 3.10 \\
\hline $\begin{array}{l}\text { grass- } \\
\text { land }\end{array}$ & 2 & 3 & 3 & 0 & 0 & 1.08 & 1.30 & 0.26 & 0.31 & 1.87 & 2.09 \\
\hline
\end{tabular}

Water depths at the outermost pressure sensor during wave records ranged from $0.49 \mathrm{~m}$ (the minimum within the data set at the reed transect of Site 1) to $1.55 \mathrm{~m}$ (the maximum within the data set at the reed transect of Site 2). Significant wave heights $\left(H_{s}\right)$ at the outermost sensor ranged from $0.01 \mathrm{~m}$ (the minimum recorded at both reed transects) to 0.31 (the maximum recorded on the salt grassland transect at Site 2) and zero-upcrossing periods $\left(T_{z}\right)$ from $0.93 \mathrm{~s}$ (minimum at the reed transect at Site 1) to $3.10 \mathrm{~s}$ (maximum at the reed transect at Site 2).

\subsection{Incident wave conditions}

A comparison of recorded water depth and incident wave heights at the outer sensors (seaward of the vegetation) shows a marked difference between the more sheltered Site 1 and the more exposed Site 2 (Figure 3). Not only was the observed water depth range and maximum incident wave height larger at the more exposed Site 2 than Site 1, but incident wave heights were also more evenly distributed across the wave height range at the more exposed Site 2 (Figure $4 \mathrm{a})$. As a result, the wave height $\left(H_{r m s}\right)$ to water depth ratio was more consistent (at around 0.2) at Site 2, compared to Site 1, with a significant relationship between water depth and wave height at Site $2\left(r^{2}=0.58 ; p<0.05\right)$ but not at Site 1 . 
Given the longer wave periods and greater water depths at Site 2 compared to Site 1 (see Table 2) and the shallow-water relationship between wave length and wave period of

$$
L=T \sqrt{ } g h
$$

where $T$ is the wave period, $g$ the gravitational constant, and $h$ water depth, it can be inferred that recorded incident wave lengths were larger (within the range 3.2 to $9.2 \mathrm{~m}$ ) at Site 2 than at Site 1 (within the range 2.0 to $7.5 \mathrm{~m}$ ). In this case, $T_{z}$ was used due to it being a more stable parameter than the spectrally derived peak wave period, $T_{p}$; the difference between these two parameters was $<0.3 \mathrm{~s}$ and $<$ $1.6 \mathrm{~s}$ at Site 1 and Site 2 respectively. Given the much lower incident wave heights at Site 1, a much greater frequency of low steepness waves $\left(\mathrm{H}_{\mathrm{s}} / \mathrm{L}<0.01\right)$ was thus observed at this location (Figure 4b).
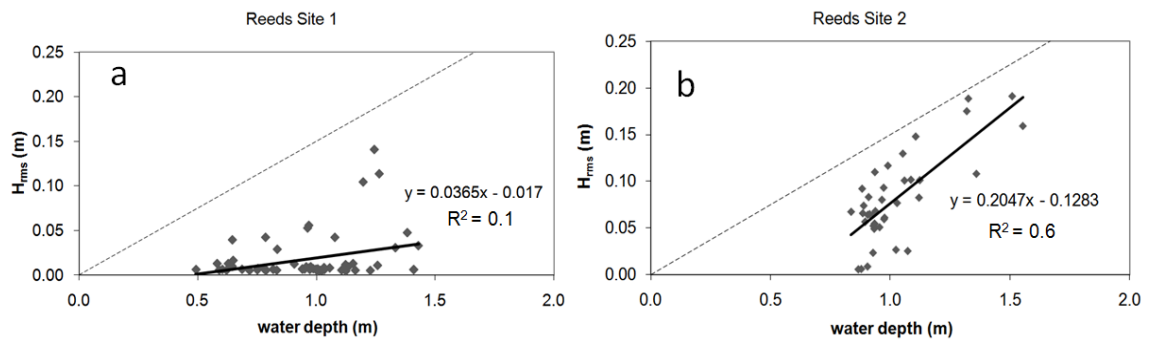

Figure 3: Water depth $(h)$ and root-mean-square wave height $\left(H_{r m s}\right)$ at the most seaward sensor of the reed transect at (a) Site 1 and (b) Site 2; stippled lines indicate the limiting $H_{r m s} / h=0.15$ condition observed on the Brouage mudflat by LeHir et al. (2000).

For those wave records $(\mathrm{N}=8)$ that coincided with northerly (onshore) wind directions (between $320^{\circ}$ to $40^{\circ} \mathrm{N}$ ), wind speeds were well-correlated with wave heights $\left(H_{s}\right)\left(\mathrm{r}^{2}=0.6\right)$ and wave periods $\left(T_{z}\right)\left(\mathrm{r}^{2}=0.70\right)$ at Site 2 , but less so at Site $1\left(\mathrm{r}^{2}=0.50\right.$ and 0.20 for correlation with wave height and wave period respectively).

Three wave records (on $30^{\text {th }}$ October 2008 at 12:00, 15:00 and 18:00 CET) were successfully recorded along the salt grassland transect, although only the central three sensors were operational along this transect at the time. Water depths during the second and third record were identical at $1.3 \mathrm{~m}$, while the first record was obtained during depths of $1.1 \mathrm{~m}$. Wind directions varied from $10^{\circ} \mathrm{N}$ to $350^{\circ} \mathrm{N}$, and $340^{\circ} \mathrm{N}$ during the three records shown in Figure 5 respectively, with speeds increasing from $140 \mathrm{~ms}^{-1}$ during the first, to $178 \mathrm{~ms}^{-1}$ on the second, and $185 \mathrm{~ms}^{-1}$ during the third record (reading records from left to right). Incident wave heights $\left(H_{s}\right)$ resulting from those conditions were $0.29,0.31$, and $0.26 \mathrm{~m}$ respectively, with wave periods of $1.9,2.1$, and $2.0 \mathrm{~s}$.

\subsection{Attenuation over salt grassland}

Figure 5 summarises the results of those three records, showing average energy dissipation per metre distance between the outermost and cliff-front sensor 

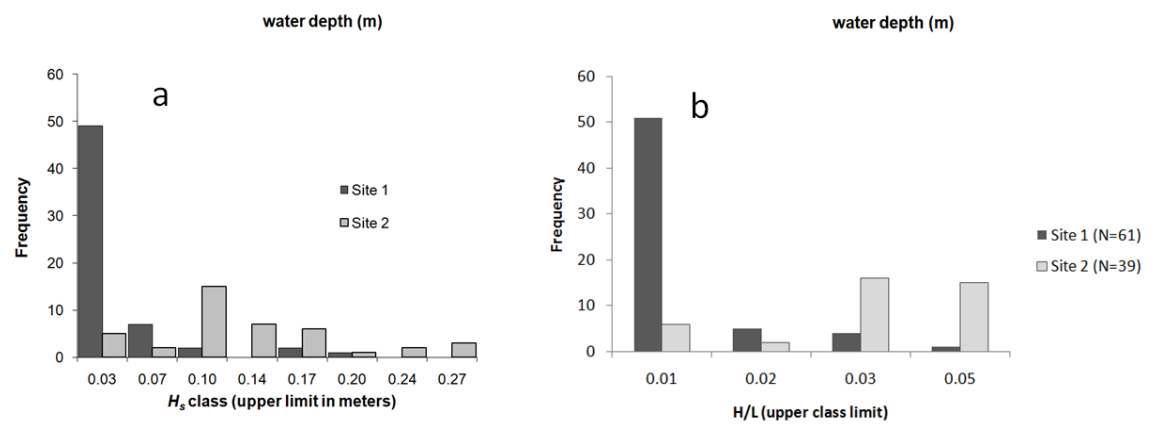

Figure 4: Distribution of (a) significant wave heights $\left(H_{s}\right)$ and (b) wave steepness $\left(H / L\right.$, with $H_{s}$ used as a representation of $H$ and $T_{z}$ used for the computation of $L$ ).

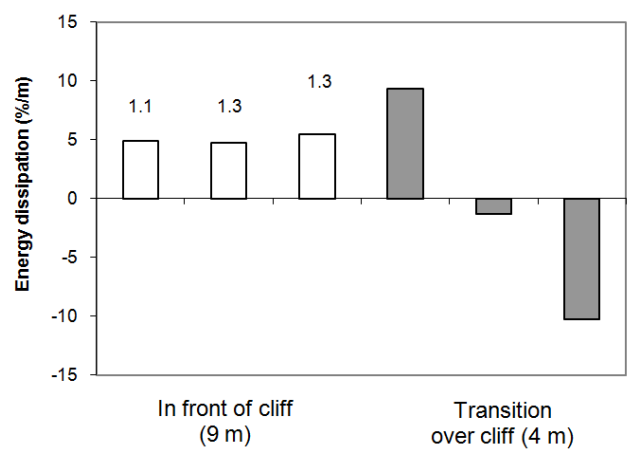

Figure 5: Energy dissipation (\%/m averaged over transect section distance (as indicated along $\mathrm{x}$-axis)) along the salt grassland transect (numbers above cliff front bars indicate water depths (in meters)).

(9 metre distance) as well as energy transformations across the cliff and onto the salt grassland (4 metre distance). Wave attenuation in front of the cliff and vegetated section of the salt grassland transect was remarkably consistent at around $5 \% \mathrm{~m}^{-1}$ during all three records (see Figure 5), while energy dissipation across the cliff onto the salt grassland was observed only on the first occasion $\left(9.3 \% \mathrm{~m}^{-1}\right)$, with energy increases observed across the cliff on the two subsequent occasions (1.3 and $10.3 \% \mathrm{~m}^{-1}$ wave energy increase on the second and third occasion respectively).

\subsection{Attenuation in reeds}

Wave energy dissipation along each of the reed transects varied considerably between Site 1 and Site 2 and for the varying meteorological conditions encountered. The dataset was divided into wave records obtained during 

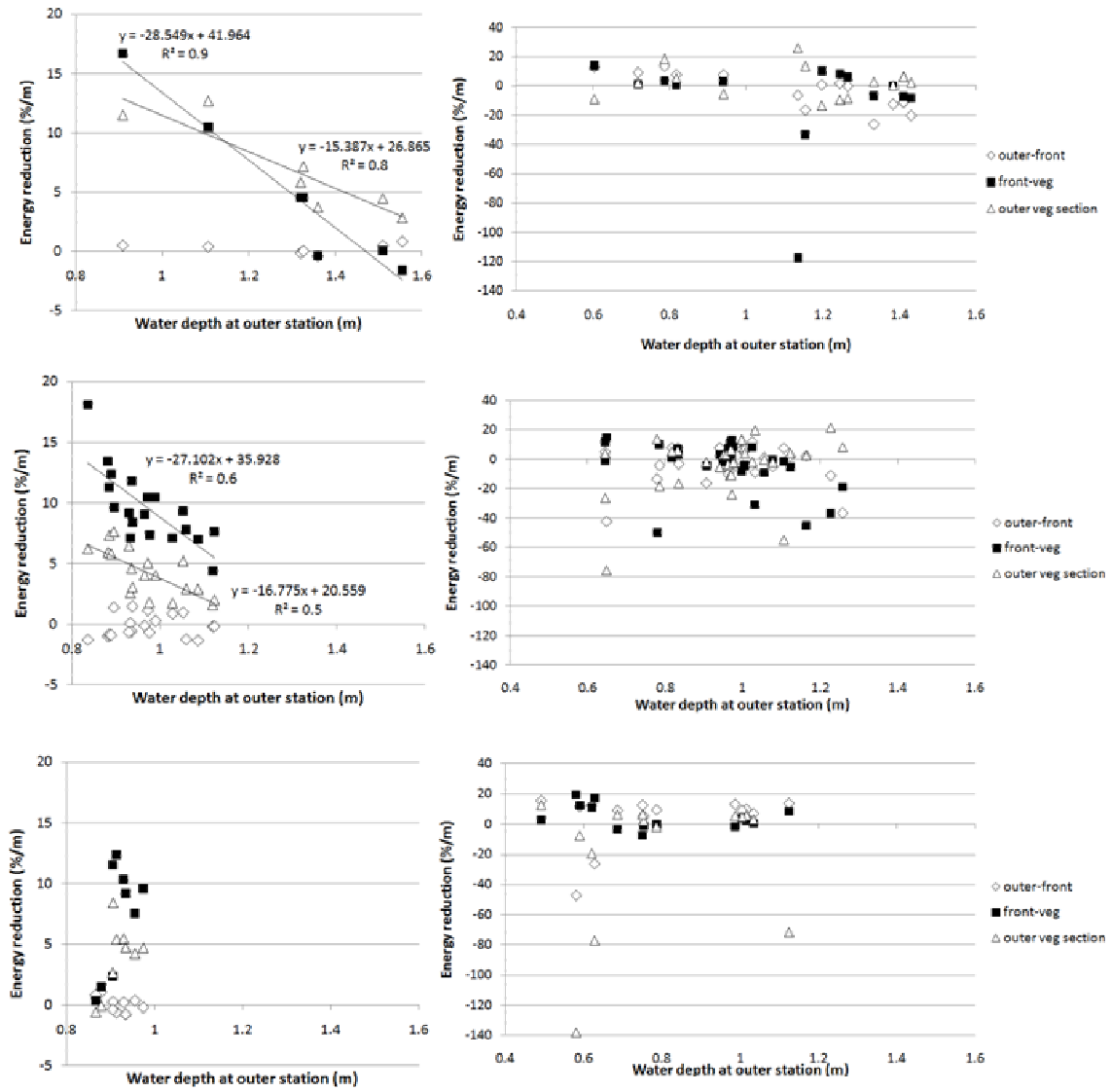

Figure 6: Relationship between water depth at outer sensor and energy reduction for Site 2 (left) and Site 1 (right), separated by wind direction category (top: northerly (onshore) winds, middle: crossshore winds, bottom: southerly (offshore) winds).

northerly (onshore, $320^{\circ}$ to $40^{\circ} \mathrm{N}$ ), southerly (offshore, $100^{\circ}$ to $260^{\circ} \mathrm{N}$ ), and cross-shore $\left(50^{\circ}\right.$ to $90^{\circ} \mathrm{N}$ and $270^{\circ}$ to $\left.320^{\circ} \mathrm{N}\right)$ wind conditions. Energy transformation between individual sensors was calculated as a spatial average $\left(\% \mathrm{~m}^{-1}\right)$ over each transect section, to allow comparison between individual transect sections. Previous studies have indicated there to be a degree of control of relative wave height $\left(H_{S} / h\right)$ on wave energy reduction over saltmarshes (e.g. Möller [12]). No such relationship was apparent at either of the reed transects of this study, with the exception of Site 2, where a positive relationship between $H s / h$ and wave energy dissipation was present when winds were from a southerly (offshore) direction $\left(\mathrm{r}^{2}=0.82\right.$ for the transition from mudflat to reeds; $r^{2}=0.80$ for the most seaward vegetated section). When only water depth is considered as a control on wave energy dissipation, however (Figure 6), wave 
energy dissipation across the open water - reed bed transition (sensor in front of the reeds to first vegetation sensor; 'front-veg' in Figure 6) as well as within the vegetation ('outer veg section' in Figure 6) was significantly related to water depth $\left(r^{2}=0.94\right.$ and 0.81 respectively, $\left.\mathrm{p}<0.05\right)$ when winds were northerly (onshore), at Site 2. There was no change in wave energy dissipation (itself negligible) with depth in the open water section in front of the reeds ('outerfront' in Figure 6).

No relationship between water depth and wave energy differences between successive stations was found under offshore wind conditions. During crossshore winds, there was, again, no relationship between wave attenuation and water depth in the open water section of the transect ('outer-front'), although a weak relationship did exist along the vegetated transect sections $\left(\mathrm{r}^{2}=0.57\right.$ and 0.53 for the transect section at the edge of the reeds and within the reeds respectively, $\mathrm{p}<0.05$ ) (Figure 6).

\section{Conclusions}

The field observations from the two cross-shore transects through reed vegetation in different hydrodynamic settings and one transect across a salt grassland transition highlight important issues concerning the functioning of these micro-tidal habitats as natural sea-defences. Four key points emerge from the analysis of the total of 103 wave records along these three transects:

i) The field data suggest that, on the more exposed coastal wetland shores of the southern Baltic Sea, incident wave energy is largely water depth limited, while on adjacent (less than $2 \mathrm{~km}$ distant), more sheltered shores, fetch limited conditions lead to much lower incident wave energy with no significant influence of water depth. Any future predictions of morphological or habitat adjustment under sea level rise scenarios (i.e. an increase in water depth; Schäfer et al. [14]) must take such depth-dependent process relationships into account.

ii) As has been shown to be the case in macro-tidal saltmarsh settings, micro-tidal grassland cliffs also result in complex wave energy transformation processes across cliffed transitions, with the existence of water depth thresholds that control the transition between energy reflection from, versus energy transmission across, the cliff face. Again, the implications are that, under rapid sea level rise, periods of cliff erosion (under high energy wave impact but relatively low water level) are likely to be followed by periods of higher energy landward of the cliff face, with associated re-suspension of sediment and/or adjustment of vegetation composition.

iii) Wave energy dissipation through reed vegetation is significant (up to $26 \% \mathrm{~m}^{-1}$ within the vegetation). Its temporal variability, during onshore wind conditions and for wave height to water depth ratios $>$ 0.1 , is controlled to a large extent by water depth, rather than incident wave height, relative wave height, or wave steepness. 
iv) The depth control on wave energy dissipation is likely to result from vertical variations in the degree of physical obstruction (e.g. biomass) to the progression of waves through the reed vegetation. Any factors that affect this vertical variation in plant matter (such as plant animal interactions) are thus as critical in determining the potential morphological and ecological impact of waves as considerations of the rate of sea level rise.

Further field studies are planned for the autumn of 2009 to expand the dataset of wave transformation over salt grassland and to more closely investigate the link between water depth, vertical variation in plant biomass, and wave transformation. The intention is also to use the wave measurements presented here in conjunction with broader ecological measurements, currently being undertaken by Greifswald University, to provide an assessment of the likely future ecological and physical functioning and management of coastal microtidal brackish grasslands.

\section{References}

[1] Allen, J.R.L. \& Pye, K., (eds.), Saltmarshes. Morphodynamics, Conservation and Engineering Significance. Cambridge University Press: Cambridge, 1992.

[2] French, J.R. Tidal marsh sedimentation and resilience to environmental change: Exploratory modelling of tidal, sea-level and sediment supply forcing in predominantly allochthonous systems. Marine Geology, 235, pp. 119-136, 2006.

[3] Bartholdy J., Christiansen, C., \& Kunzendorf, H. Long-term variations in backbarrier saltmarsh deposition on the Skallingen peninsula - the Danish Wadden Sea. Marine Geology, 203, pp. 1-21, 2004.

[4] Knutson, P.L, Brochu, R.A., Seelig, W.N. \& Inskeep, M. Wave damping in Spartina alterniflora marshes. Wetlands, 2, pp. 87-104, 1982.

[5] Möller, I., Spencer, T., French, J.R., Leggett, D.J. \& Dixon, M. Wave transformation over salt marshes: A field and numerical modelling study from North Norfolk, England. Estuarine, Coastal and Shelf Science, 49, pp. 411-426, 1999.

[6] Möller, I. \& Spencer, T. Wave dissipation over macro-tidal saltmarshes: Effects of marsh edge typology and vegetation change. Journal of Coastal Research, SI36, pp. 506-521, 2002.

[7] Tyler, G. Regional aspects of Baltic shore-meadows. Vegetatio, 19, pp. 6086, 1969.

[8] Meier, H.E.M., Broman, B. \& Kjellström, E. Simulated sea level in past and future climates of the Baltic Sea. Climate Research, 27, pp. 59-75, 2004.

[9] Gillner, V. Salt marsh vegetation in southern Sweden. Acta Phytogeograhica Suecica, 50, pp. 97-104, 1965. 
[10] Jeschke, L. Vegetationsdynamik des Salzgraslandes im Bereich der Ostseeküste der DDR unter dem Einfluss des Menschen. Hercynia, N.F., 24, pp. 321-328, 1987.

[11] Seiberling, S., Stock, M. \& Thapa, P.P. Renaturierung von Salzgrasländern bzw. Salzwiesen der Küsten. In: Zerbe, S. \& Wiegleb, G. (eds.), Renaturierung von Ökosystemen in Mitteleuropa. Springer: Heidelberg: pp. 183-208, 2009.

[12] Möller, I. Quantifying saltmarsh vegetation and its effect on wave height dissipation: results from a UK East coast saltmarsh. Journal of Estuarine, Coastal and Shelf Sciences, 69(3-4), pp. 337-351, 2006.

[13] Moeller, I., Spencer, T. \& French, J.R. Wind wave attenuation over saltmarsh surfaces: Preliminary results from Norfolk, England. Journal of Coastal Research, 12(4), pp. 1009-1016, 1996.

[14] Schäfer, C., Zerbe, S. \& Seiberling, S. Mögliche Auswirkungen des Klimawandels auf die Salzgrasländer an der Ostseeküste. Eine Analyse am Beispiel der Küste Mecklenburg-Vorpommerns. Naturschutz $u$. Landschaftsplanung, 40, pp. 361-366, 2008. 